\title{
Islamic defensive architecture along the eastern coast of Algeria: the Fusula Ribat and its mosque (Annaba)
}

\author{
Samia Chergui a ${ }^{\text {, Samira Haoui }}{ }^{\text {b }}$ \\ Institut d'Architecture et Urbanisme - Laboratoire Environnement et Technologie pour l'Architecture et le Patri- \\ moine - Département Patrimoine Urbain et Architectural - Université Saâd Dahleb, Blida 1, Algeria \\ a cherguisamia@gmail.com; ${ }^{b}$ haouisamira@gmail.com
}

\begin{abstract}
The ribat in Bouna (present day Annaba), also called the Fusula Ribat, dominates the promontory of the hill with the same name and overlooks the port of the town. This defensive structure, whose typology dates from the Fatimid period, belonged to a chain of ribats marking Islamic territory along the length of the Mediterranean coast. It was concealed under the Sidi Boumerouane Mosque. Thus, through a series of transformations, the site became a veritable military-religious complex. The recent process of patrimonialization, as well as the restoration project at the complex, has revealed the structure of the ribat, leaning against the wall and essentially forming the foundations of the first mosque of the town. The aim of this article is, on the one hand, to bring new knowledge, as much technical as historical, about this fortified structure, which has largely been ignored by historical research until now, and on the other, to carry out the restoration project of this edifice, which has now been classed as national heritage.
\end{abstract}

Keywords: Ribat, Islamic fortification, Annaba, architectural stratification.

\section{Introduction}

From the outset, our interest was focused on the Fusula Ribat and the Sidi Bu Marwân Mosque, where the latest restoration work aimed to go beyond their authenticity, which had been tainted by damaging alterations in the nineteenth and twentieth centuries, to examine a patrimony reconciled with both its history and integrity. The reputation of this site is not only linked to the town of Annaba (formerly called Bûna), where it has stood for ten centuries, but also to its defensive position overlooking one of the most beautiful bays, on the eastern coast of Algeria, which had remained impenetrable until the nineteenth century (Fig. 1).

If the local historian, al-Chaykh Ahmad AlBunî, is to be believed, then, the construction of the Sidi Bu Marwân mosque on the Fusula Ribat was completed by Admiral Amir al-rahl Abu Layth al-Bunî in the year 425 of the Hegira, that is to say, approximately $1033 \mathrm{AD}$ (Douib, 2008, p. 296). This new mosque at Bûna al-Haditha (modern Bûna) was named after Abu Marwân al-Bunî, a legal expert, well-versed in Quarranic exegesis, who had studied at Cordoue in Andalousia, in the East, and later in Kairouan and Tlemcen, before settling with his family in Bûna (Derdour, 1982, p. 169). On his death at the beginning of the twelfth century, approximately 1111AD (505 of the Hegira), Sidi BuMarwân alBunî was buried inside the mosque beside its founder, Abu Layth al-Bunî, to whom the site owes its reputation as a veritable militaryreligious complex (Derdour, 1982, p. 249). 
The present article echoes of the restoration and conversion work carried out between 2008 and 2016. It is a written account of the active choices and decisions made, based on readings of both a philological and stratigraphic nature. In fact, through this article, we will demonstrate that the restoration and evaluation project of the mosque, erected on the coastal fringes of the town, which formerly dominated the sea to the east, and defended the town to the west. It offered us an opportunity to re-discover the structure of the medieval ribat and examine its connection to this place of worship. A project of this scale also aimed to reconcile the edifice with its local military history and its maritime landscape.

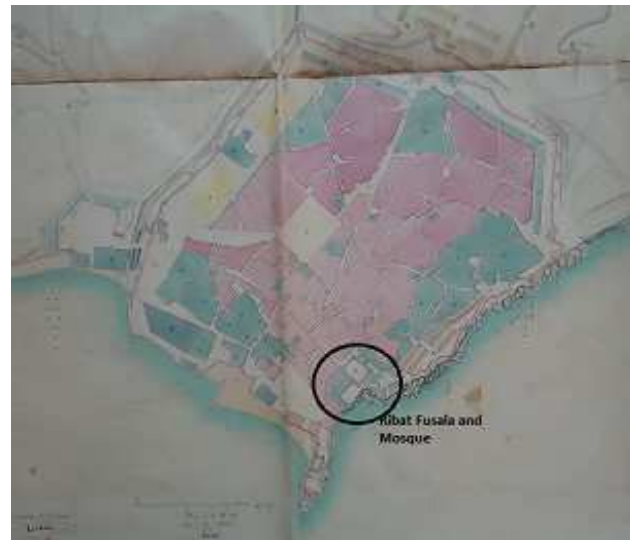

Fig. 1. Location of the Ribat Fusala and its mosque Sidi Bû Marwân overlooking Annaba bay (MAP Funds, Paris).

\section{The Origins of the Ribat and its mosque}

This defensive work, built into a rock, just below the Sidi BuMarwân Mosque, belongs to a chain of maritime ribats, built along the coast of Ifriqiya, to assure the security of the territory, on the one hand, and the departure of Muslim expeditions to the European coast, on the other. The town of Bûna, both a port and naval base, was not only attacked by a coalition of Genoese, Pisans and Provencals in 1033, but was also under threat from the European crusades of the eleventh century (Dahmani, 1982, p. 47).

The battle for control of the Mediterranean, and the need to protect the territory from maritime European attack, was the motive behind the redevelopment along the coast and the reinforcement of its defensive structures. The founder of the Sidi BuMarwân Mosque, The Admiral Abu Layth Al-Bunî, was commissioned to oversee the security of the Chatt al-Murdjan, home to the coral fishing industry. This superior naval officer undertook, therefore, the construction of several ribats between Bone and Cale, including the one at Fusula which he concealed under the said mosque. This military-religious complex has failed to conserve the authenticity of either its spatial or architectural components. It was converted into a military hospital following the French conquest; the subsequent transformations and vertical extensions were not made without extensive damage to the site.

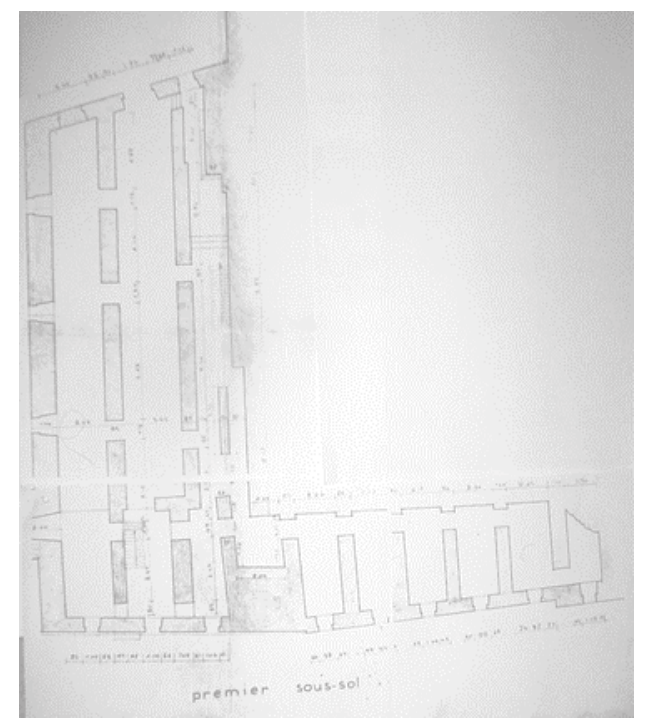

Fig. 2. Survey of the first level underground of the ribat Fussala, 1967 (Archives of OGEBC).

Nevertheless, archives dating from the beginning of the colonial period, supported by the ruins visible at the site, allow for a description of this defensive edifice. The side of the ribat parallel to the southern wall of the mosque is organised in three parallel bays, which separate thick, masonry walls, with bases made from reused stone, probably taken from the ruins at Hippone. Cradles of brick, laid longitudinally, make up the vaults. The posterior part of the building holds a passage, in the form of a corridor, which pro- 
vides access to two very long, adjoining rooms. Four sets of openings, in the load-bearing walls that enclose the bays, are, according to the traces of the ruins, aligned in a direction that seems to converge on the same point in the maritime landscape, as if to allow shots to be fired from this fortified edifice (Figs. 2 and 3).

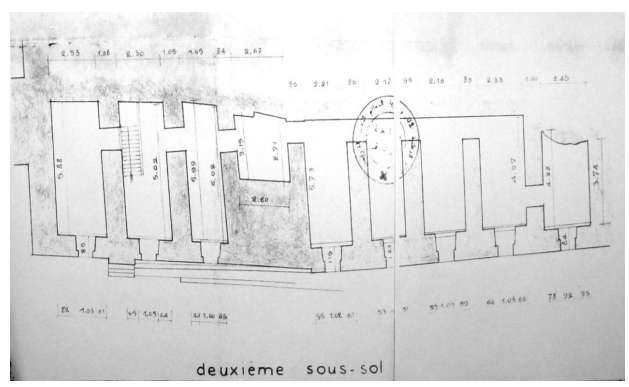

Fig. 3. Survey of the second level underground of the ribat Fussala, 1967 (Archives of OGEBC).

The second side of the ribat, perpendicular and parallel to the eastern wall of the mosque, is composed of a single bay, divided into several small transverse rooms. Completely parallel, and communicating with each other by means of a set of aligned doorways, they provide access into the farthest part of the building, ending, at the point where they cross with the corridor, in a sort of vestibule, before continuing in a southerly direction to join the other part of the building, situated to the right of the first. Each of these rooms, separated by shear walls, opens out onto the sea by means of splayed windows, cut into a wall which once formed the base of the old, seafacing façade of the Bûna Mosque, offering protection to the northern coast of the region. Work carried out in 1963, to reconstruct the basement, which had collapsed following deflagrations at the port, transformed the ancient structure of the mosque and the ribat. Modern structures, made from reinforced concrete and fixed to the rock face, are perfect examples of this.

A veritable jewel, the Sidi BuMarwân Mosque is considered as one of the most beautiful examples of Zirid and Hammadid architecture. In its original form, it is composed of a prayer room, punctuated with re-used, antique columns that extend to the north into a quadrangle, which is surrounded by galleries of arcades where a narthex, an oratory reserved for funeral prayers (mussalla al-djnayaz), a room for ablutions (maydha) and a madrasa are all found.

The prayer room seems to have kept its original dimensions and is almost square in shape, measuring approximately 19,20 m deep and 19,60 m wide. It is composed of seven naves and seven bays, covered with pointed vaults in a manner similar to the Zirid mosque in the town of Sfax in Tunisia. Two domes, of which their underside is decorated with a zigzag pattern, mark the ends of the central nave: one well in front of the mihrab, and the other, at the point where the bay and the narthex gallery meet. Although we have been able to pinpoint the exact position of the inner dome, we cannot, unfortunately, describe it due to the schematic nature of the available documents, namely the Berbrugger drawing, conserved in the archives at Vincennes in Paris, which gives us only a rough outline and the longitudinal profile of the two domes.

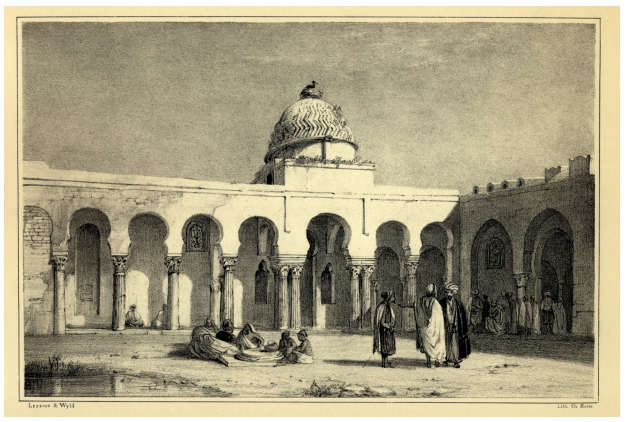

Fig. 4. View of the Sahn of the mosque (Lithography Lessore and Wyld in 1832).

Large tubes, in keeping with the pure architectural tradition of Ifriqaya, stretch from two cylindrical and square drums to the top of the dome, where they radiate outwards. The Sahn or courtyard of the mosque partially covers a cistern which is thought to be of antique origin. Called a Madjin, it has a service stairs, situated at the back, which gives access to undergrounds spaces to allow for regular upkeep. The cistern is covered by pointed vaults, supported by antique drums, mounted on capitals (Fig. 5). 


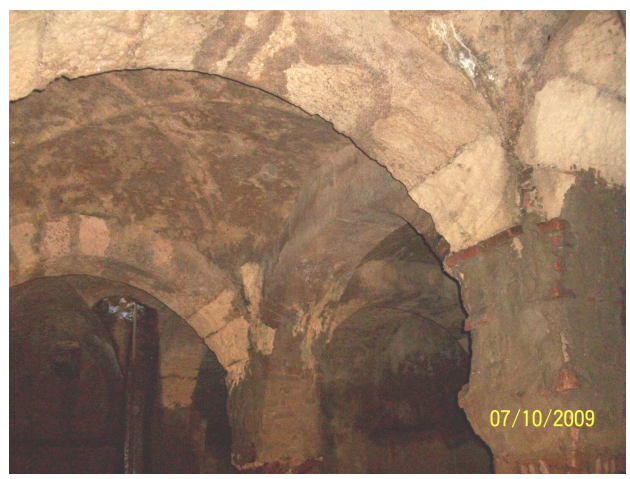

Fig. 5. Vaults covering the medieval cistern (AUA photography, Annaba, 2009).

A minaret can be found at the north-east corner of the courtyard. In the interest of defence and of control, this square-based tower is, in fact, a veritable lookout post which dominates the Bone coastline, stretching upwards to a great height to allow for the observation and surveillance of both land and sea. Although the prayer room is built into the rock face, the terrace on its eastern and southern sides partially covered at both ends with vaults, marks, today, the basement level which undoubtedly corresponds to the Fusala Ribat on which this mosque was built. In fact, the Sidi BuMarwân Mosque, which stands on the promontory of the Fasula hill in the highest part of the town of Bûna al-Haditha, was built on top of the old fort, with the same name, and is, in fact, an extension of it.

\section{Transformations at the military-religious complex}

During the Ottoman period, the courtyard in front of the prayer room was narrowed to allow for an ablutions room. These alterations not only caused changes in the ordinance and surface area of this outside space, but offset the dome, formerly above the terrace, to a place in front of the oratory door. After the occupation of the mosque by the French army, during the early days of their conquest of the town of Bûna in 1832, in order to convert it to a hospital, it was subject to a thorough overhaul, which resulted in serious damage.

Since this transformation, a new floor has been built above the terrace which needed a rein- forcement of the supports inside the prayer room. As a result, two rows of columns were encased in massive squares of masonry and new pillars were built to strengthen the columns of the narthex. On the outside, a large tiled roof, with two slopes, was erected over the new storey in the form of an attic, which, nevertheless, overlooked the terrace and eliminated the battlements that had crowned the edifice all around its perimeter. The minaret, too, probably in the hope of giving coherence to the edifice, in terms of its size and composition, was also overhauled; the height of the overlapping towers was increased and the small terminal dome was replaced by a cone. However, even more serious still, the two domes covering the central nave of the oratory were completely destroyed, which permanently disfigured the monument (Fig. 6).

The Sidi BuMarwân Mosque was only restored as a place of Muslim worship in 1945. It was from this period that the mosque started to generate an interest which became apparent in February 1947 with the publication of the memorandum Note sur la Mosquee Sidi Bou Marwân a Bone. Although the author of this work is not mentioned, we think that it is probably Georges Marçais. This report shows many similarities with a more elaborate and detailed article on the same subject, published by this architect in 1950 (Marçais, 1950, pp. 225-236).

In this memorandum, attention is focused on the historical and architectural value of the edifice, both sorely tested by the transformations and damage to which it had been subjected. Moreover, the author recommends that these acts of "vandalism" be repaired and that the iconographic documents, established during the early days of the conquest, could prove useful thanks to their precision. A record of the structure of the edifice was written, during the same period, for the Historical Monuments Department of the Algerian government, by F. Buscail, the architect cited and thanked by G. Marçais for the quality of his drawings in his article about the mosque in Bûna, which was published in 1950.

Another document, written in 1967 and entitled Rapport de la mission du 11 Mai 1967, is a sort of transcript of a meeting between Abderrah- 
mane Bouchama, architect for the Ministry of Habous, and Andre Ravereau, architect for the Department of Historical Monuments. It followed a landslide that occurred on May $9^{\text {th }}$, 1967 , caused by a clean-up operation to remove the debris from the landslide of January 1965, which resulted in the collapse of a large part of the terrace and two vaulted, basement floors at the ribat. The landslide was blamed on the state of degradation of the slate rock which supported the weight of the prayer room. Moreover, the steep $60^{\circ}$ incline of the slate strata, which caused the rock to break away, anticipates recurrence in the future.

\section{The basis of the restoration project: sources and stratigraphic readings}

The restoration project was based on different findings taken from both written and lithographic sources, which were then cross-checked with stratigraphic readings carried out on the monument itself. Stratigraphic analysis applied to architecture, through the material evidence revealed in the masonry, allows for the identification and documentation of the different constructive periods of the building. The construction process, with its different phases of extension, demolition, substition and transformation, can often be seen through a series of traces, which the skilled eye not only recognises but can equally understand and explain. In this way, then, the materials and construction techniques can be better appreciated.

This step was considered to be the most appropriate one for a monument of such tremendous historical value. Any mention in written sources of a ribat or a masdjid is rare. Ibn Hawkal makes no mention of the mosque in the ninth century but he does refer to a ribât (Ibn Hawqal, 1964, p. 77). The first description of a masdjid dates from the eleventh century and was made by Chayk Ahmad Al-Bunî. It confirms that this mosque was constructed on a hollow rock where, inside, the Fusala ribat was built. It also talks about a garden planted with trees and flowers, close to the main entrance of the mosque. Al-Bustāne constituted a green corridor within the town where the scent of orange blossom, roses and jasmine filled the air (Al-Bûni Ben Kâsim, 2007, p. 181).

From the lithographic observations produced during French military expeditions between 1830 and 1845 , it is easy to get a general idea of the mosque and its dependencies before their extensive transformation.

One of these iconographies, attributed to Lessor and Wyld, presents a view of the sahn at the mosque, taken from the north-west angle. It shows not only a part of the courtyard, but also the façade of the prayer room, preceded by the narthex gallery (Fig. 4). The latter is edged by an

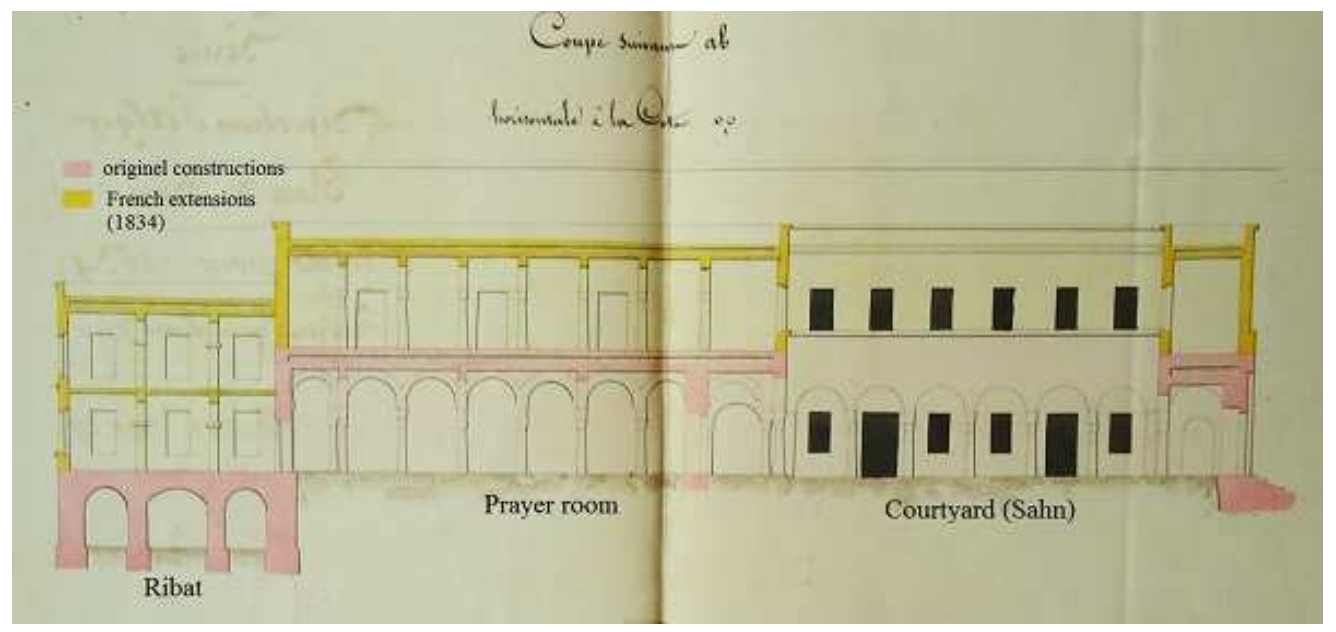

Fig. 6. Global section relating Ribat to the mosque (Archives of Vincennes, Paris). 
arcade composed of ridged columns, which support overhanging, rounded arches. The barrels and capitals are antique, taken and reused from the site at Hippone. The dome, which marks the entrance to the prayer room, just beyond the narthex gallery, rests on the prayer room wall and on the arches, grouped in threes. It is eccentric in relation to the arches of the gallery. Its cap is mounted on a double drum: the bottom one is square and the middle one is cylindrical in shape. It is decorated, on its surface, with zigzags.

The damage to the surroundings of the complex and its rupture with the coastline happened abruptly. The edifices next to the mosque were quickly destroyed, during colonisation, so that military and administrative buildings could be built. The subsequent conversion of this site into a military hospital left few traces of its original state. In the absence of actual information, a stratigraphic study allowed us to reconstitute the history of the monument. The walls on the ground floor show structures from different periods. The original ones from the Hammidid period can be easily recognised from their mixed frame of stone and brick, with a mortar of lime and a pink-coloured soil. The second structures date back to the French colonial period and show a mixed frame made from stone and roughly cut bricks, filled with a mortar of lime and red earth. The last structures resulted from a contemporary intervention of which the dominant materials were reinforced concrete for the structural body, and crushed bricks for the fillings.

As for the basement, which was once the ribat, it has similarly undergone extensive transformations, making it difficult to read its structural composition. Nevertheless, it is possible to recognise not only the original structures from the Hammadid period, but also that, those dating from the French occupation, were made in two stages: the first, reconstruction; the second, alteration followed by puttying and filling. In a final contemporary intervention, modern structures of reinforced concrete were introduced (Figs. 7 and 8).

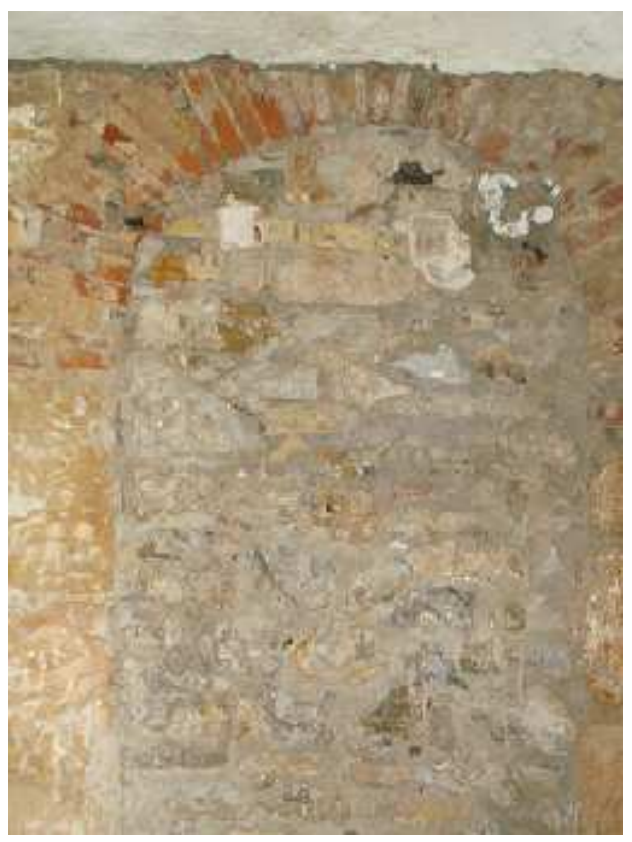

Fig. 7: Ribat: original arched opening built in stones obstructed in the nineteenth century.

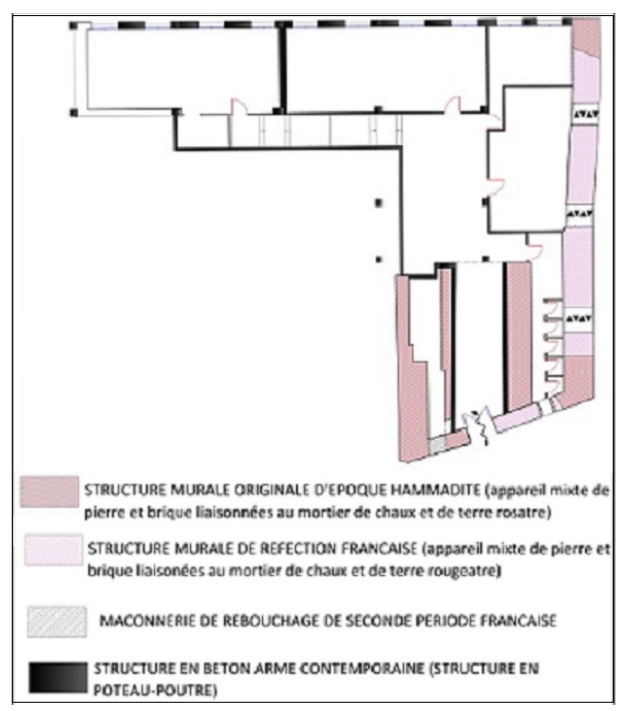

Fig. 8. Stratification plan of ribat (S. Chergui). 


\section{Conclusion}

The restoration and evaluation project of the oldest mosque in Bûna, present-day Annaba, presents both this place of worship and the ribat in a new light. Throughout this study, the aim has been to go beyond the idea of a monument, reconverted, even damaged, to examine a patrimony reconciled with its history, albeit shocking, on the one hand, and its physical and social environment, on the other.

The historic evolution of this edifice reconstituted from several available sources, elucidates the unique character of the Fusala Ribat in terms of its form, totally or partially trogloytical, and its strong relationship with the place of worship.
This configuration, both functional and structural, contributes to the knowledge about the typologies of the defensive structures along the coast of Ifriqaya. Like the ribat in Sousse, for example, the Fusala Ribat confirms interdependence between the defensive and the religious functions of the ribats in Ifriqaya, illustrated by both the prayer room and the minaret. Both its trogloytical structure, and its attachment to the rock face, bears witness to the specific variations of these structures.

Excavations, which were missing within the framework of this restoration project, would certainly add to, and clarify, our findings concerning these medieval structures buried underground.

\section{Bibliography}

Al-Bûni Ben Kâsim, A. (2007). Al-ta arîf bi Bûna-t ifriqya, balad sayyidi Abî Marwân, Dahmani Ed., Annaba.

Dahmani, S. (1982). Annaba, Art et Culture, Ministère de l'Information Ed., Alger.

Dahmani, S. (2013). "Essai de restitution du complexe monumental d'Abû Marwân de Bûna-Annaba", Ikosim, 2, Alger, pp. 109-115.

Derdour, H. (1982). Annaba. 25 siècles de vie quotidienne et de luttes, SNED, Alger.

Douib, A. (2008). L'Ifriqiya à l'époque ziride, Histoire de la Tunisie: “Le Moyen Age”, Sud Ed., Tunis, tom. II.

Harris, E. (1993). Practices of Archaeological Stratigraphy, Academic press limited, London \& New York, p. 169.

Ibn Hawqal. (1964). Configuration de la terre (Kitab surat al-ard), Kramers, J.H.; Wiet, G., trad., Maisonneuve/Larose Ed.

Mannoni, T. (2005). "Quels types de rapport entre monument et sources écrites", in Texte et archéologie monumentale, Approches de l'architecture médiévale, Mergoil Ed., Autun, pp. 78-81.

Marçais, G. (1950). La Mosquée de Sidi Bou Merouan à Bône, William Marçais, M., G.P. Maisonneuve Ed., Paris, pp. 225-236.

Marmol, L. (1667). Description de l'Afrique, Ablancourt, N.P., trad., Thomas Iolly, Paris, 3 vols. 
